\title{
Entry requirements to the auditing profession: a need for harmonisation
}

\author{
Maria. A. Garcia-Benau • Ana Zorio
}

Published online: 6 February 2013

(C) International Network of Business and Management 2013

\begin{abstract}
This paper analyses the current situation as regards entry requirements to the accounting profession from an international perspective. Auditing is a public interest service so it is regulated in different jurisdictions. Our results show that even though this service is dominated by global multinational companies and entry barriers to foreign markets seem to be falling, there is important diversity among entry requirements to the audit profession in the countries analysed. The authors support the need for international harmonization in this field by means of promoting global acceptance of the standards set by the International Accounting Education Standards Board from the International Federation of Accountants. This paper is extremely timely given the fact that the Spanish standard setter is about to make regulatory changes in this regard and has created a discussion group to this end.
\end{abstract}

Keywords Auditing · Entry requirement · IES · IAESB · IFAC

\section{Introduction}

Access to the Spanish Official Registry of Auditors (Registro Oficial de Auditores de Cuentas, ROAC) was regulated by Law 19/1988 on the Statutory Auditing as well as by the subsequent implementing regulations and by orders convening examinations and some resolutions of the Instituto de Contabilidad y Auditoría de Cuentas (ICAC), the Spanish accounting and auditing standard setter which depends from the Ministry of Economics. There have recently been some changes in the regulations that establish the requirements to become an auditor that have led the

Maria. A. Garcia-Benau · A. Zorio $(\bowtie)$

Departament de Comptabilitat, Universitat de Valencia, Valencia, Spain

e-mail: ana.zorio@uv.es

Maria. A. Garcia-Benau

e-mail: garciab@uv.es 
Spanish accounting standard-setter (ICAC) to create a think tank to propose amendments to the current legislation on admittance to ROAC. We are referring to the passing of Directive 2006/43/EC and Law 12/2011, ${ }^{1}$ amending Law 19/1988 on the Statutory Auditing.

The audit profession has had to adopt changes in its methodology (Khalifa et al. 2007) and education (Armitage 2008; Allen and Woodland 2010; Crawford et al. 2011; O'leary 2012) to face an increasingly complex business environment (Defond and Francis 2005), which is becoming more and more global. The audit market is also dominated by global players. Hence, from our point of view, it is very timely to analyse whether there is consistency internationally as regards entry requirements to this profession.

Therefore, this paper has a twofold aim. We intend to analyse the current situation of entry to the auditing profession in an international context and also to offer some reflections on how to approach change in line with the globalised environment in which the profession provides its services. In particular, we analyse the situation of ten international benchmark countries to conclude that there is a need to progress towards European and international harmonisation of entry requirements to the auditing profession.

After highlighting the reasons for this study in the above paragraphs, the second section summarises the legal framework for auditor education and actions underway in ten countries, six from the European Union and four non-European countries. In the third section, we present the requirements for entry to the auditing profession in Spain, emphasising the most controversial points in the debate. Finally, the conclusions highlight the need to harmonise legal requirements of training and education for entry to the auditing profession, bearing in mind that we live in a globalised world.

\section{Legal framework}

The audit supervision model adopted by Europe is laid down by Directive 2006/43/ EC. This Directive maintains access to the auditing profession through the "academic route" and the "professional route" (with long-term practical experience, see Articles 6 and 11).

Under Article 6, a person may carry out an audit only after 'having attained university entrance or equivalent level, then completed a course of theoretical instruction, undergone practical training and passed an examination of professional competence of university final or equivalent examination level'.

The examination of professional competence guarantees the level of technical knowledge of statutory audit subjects and the ability to put that knowledge into practice. Article 8 in Directive 2006/43 lists the subjects to be covered by a test of theoretical knowledge (Table 1).

\footnotetext{
${ }^{1}$ In particular Article 7 on authorisation and registration in ROAC, that will shortly be the object of implementing legislation.
} 
Table 1 Subjects of theoretical knowledge to be covered by the test

Financial reporting subjects

(a) General accounting theory and principles;

(b) Legal requirements and standards relating to the preparation of annual and consolidated accounts;

(c) International accounting standards;

(d) Financial analysis;

(e) Cost and management accounting;

(f) Risk management and internal control;

(g) Auditing and professional skills;

(h) Legal requirements and professional standards relating to statutory audit and statutory auditors;

(i) International auditing standards;

(j) Professional ethics and independence.

Other related subjects

(a) Company law and corporate governance;

(b) The law of insolvency and similar procedures;

(c) Tax law;

(d) Civil and commercial law;

(e) Social security law and employment law;

(f) Information technology and computer systems;

(g) Business, general and financial economics;

(h) Mathematics and statistics;

(i) Basic principles of the financial management of undertakings

According to Article 10 of the Directive, a trainee shall complete a minimum of 3 years' practical training in, inter alia, the auditing of annual accounts, consolidated accounts or similar financial statements. At least two thirds of such practical training shall be completed with a statutory auditor or audit firm approved in any Member State. Member States shall ensure that all training is carried out with persons providing adequate guarantees regarding their ability to provide practical training.

We consider that in addition to the above mentioned European Directive, other pronouncements should also be considered such as the revised model of the UNCTAD-ISAR (2003) accounting syllabus, the Common Content initiative supported by some European countries (see The Common Content Project 2010a, b, c, d, e) and even more importantly as a global reference, the International Education Standards (IES) issued by International Accounting Education Standards Board (IAESB) from the International Federation of Accountants (IFAC) (IFAC 2010a).

In this regard, we should also not lose sight of the harmonisation process that has led the European Union though EC Regulation 1606/2002 to accept the International Financial Reporting Standards issued by the International Accounting Standards Board (IASB) for certain European enterprises (Garcia-Benau and Zorio 2004) and through Directive 2006/43/EC to propose the adoption of the International Standard on Auditing (ISA) issued by the International Auditing and Assurance Standards 
Board from the IFAC. These standards have been recently clarified (Zorio et al. 2010).

These European measures have been proposed with the aim of progressing towards harmonising accounting and auditing. Therefore, we consider that in the field of auditing, in addition to ISA (technical standards), auditor training standards should be harmonised. In our opinion, we need to gain further knowledge and valuation of the suitability of IAESB standards that constitute training standards for entering the auditing profession and for the necessary ongoing training of auditors (see McPeak et al. 2012). IAESB standards will also be clarified through a Clarity Project (IFAC 2010b). In this paper, we present our opinion on whether these training standards should at some point become the benchmark for the European Union, in particular as regards the initial training of auditors.

For the purposes of this study, the following eight IES and three International Education Practice Statement (IEPS) published to date are of special interest.

IES 1: Entry Requirements to a Program of Professional Accounting Education

IES 2: Content of Professional Accounting Education Programs

IES 3: Professional Skills and General Education

IES 4: Professional Values, Ethics and Attitudes

IES 5: Practical Experience Requirements

IES 6: Assessment of Professional Capabilities and Competence

IES 7: Continuing Professional Development: a Program of Lifelong Learning and Continuing Development of Professional Competence

IES 8: Competence Requirements for Audit Professionals

IEPS 1: Approaches to Developing and Maintaining Professional Values, Ethics, and Attitudes

IEPS 2: Information Technology for Professional Accountants

IEPS 3: Practical Experience Requirements-Initial Professional Development for Professional Accountants

A new aspect of these international standards is the consideration of skills classified according to IES 3 into intellectual, personal, interpersonal and communicative, organisational and business world skills. All of them enable auditors to learn how to organise information and analyse it critically; manage their daily individual activity effectively, enabling them to manage their work efficiently and improve relations with third parties.

We have analysed the information provided by the IFAC in ten countries (Table 2) the national accounting bodies of which have provided information in this field (see also Quick et al. 2008). Appendix illustrate the differences with a comparative table.

France, Germany, Ireland, Italy, the Netherlands and the United Kingdom as member countries of the Common Content clearly support IES. The United Kingdom participates very actively in IAESB. Ireland places great value on developing information technology skills. Japan and USA have included IES in their regulations. Spain has not incorporated them into its legislation. Canada and China want to introduce IES; Canada in particular already follows IES on the valuation of professional skills and competences (IES 6). 
Table 2 Countries analysed in this paper

\begin{tabular}{ll}
\hline Country & Accounting body responding to the IFAC on entry requirements \\
\hline Germany & Institut der Wirtschaftsprüfer, Wirtschaftsprüferkammer \\
Canada & The Canadian Institute of Chartered Accountants \\
China & The Chinese Institute of Certified Public Accountants (CICPA) \\
Spain & Instituto de Censores Jurados de Cuentas de España (ICJCE) \\
USA & American Institute of Certified Public Accountants \\
France & Compagnie Nationale des Commissaires aux Comptes \\
Ireland & Chartered Accountants Ireland, The Institute of Certified Public Accountants in Ireland \\
Italy & Consiglio Nazionale dei Dottori Commercialisti e degli Esperti Contabili \\
Japan & The Japanese Institute of Certified Public Accountants \\
UK & The Institute of Chartered Accountants in England \& Wales \\
\hline
\end{tabular}

Theoretical training for entering the auditing profession is highly valued in all countries and it is regulated and specified in all of them, except for China where no particular theoretical training is specified. In most countries, universities are responsible for providing theoretical teaching, normally in the form of a master's degree course. In the United Kingdom, it is also possible to provide theoretical training in some private teaching centres. Italy specifies that universities providing training must be accredited.

Within the theoretical training phase, the role of the Ministry of Education, professional corporations and other bodies is often emphasised. For example, in Ireland and Canada, the corporations themselves establish the requirements and collaborate with the universities to produce the syllabus. In France, the requirements are laid down by the Ministry of Education and the Conseil Supérieur de l'Ordre des Expert-Comptables and the Compagnie Nationale des Commissaires aux Comptes although there is an alternative aptitude test contemplated in IES. In Germany, there are two-year Master's degree courses oriented at practical training. Theoretical training in Japan is in accordance with IES.

As regards practical training, in Canada, at least 3 years' practical experience is required, and 2 at senior level as in France where training must take place within a 5 -year period. Germany and Italy require 3 years' work experience. China and Japan require 2 years' work experience; Japan considers that work experience can be done before or after the examination, and also wants to introduce and unify the figure of the mentor and propose strict monitoring and evaluation of the practical experience that can be gained before, during or after the theoretical training.

The figure of the work experience mentor has been established in some countries. In France and the United Kingdom, there is a system of controlled mentoring with an updated list of authorised mentors and candidates in the process of practical training. During this training period, trainee auditors must acquire diversified experience in different areas of audit work. Ireland has a register of activities and each candidate submits skills form signed and assessed by his/her mentor that must be presented to the auditing corporation or body. In the USA, there is no mentoring 
system, but each candidate must present a report on his/her practical training. In China, there is an authorised tutor for practical experience, but apparently no control or monitoring of the practical work undertaken.

In many of the countries, the entry test or examination is held on a regular basis. In Canada, the United Kingdom and Germany, it is held every 6 months, whereas China, France, Ireland and Japan hold one every year.

Some countries such as Italy, France and Germany require that the applicants pass an oral test in addition to the written test. In particular, in France, the written test is case based and the oral test concerns the practical experience and discussion of a topic; whereas in Italy, the oral part focuses on issues related to ethics and professional values. However, other countries only have a written test such as it is the case in Ireland, Spain, the United Kingdom and the United States.

As for the content of the examination, it is worth emphasising that in Ireland, knowledge of the International Standards on Auditing (ISA) has been a requirement since year 2009. In Italy, the contents of the test are defined in the legislation itself. In Canada, the examination also has to assess competences and skills according to IES 6.

\section{Current situation in Spain}

Law 12/2010, on the Statutory Auditing states that it is 'a service provided to the audited entity that affects and interests not only of that entity but also of third parties'. Directive 2006/43/EC emphasises that audits facilitate 'the orderly functioning of markets by enhancing the integrity and efficiency of financial statements'. The Green Paper (European Commission 2010; Humphrey et al. 2011) adopts a similar standpoint as it establishes that audit should be a key contributor to financial stability. Indeed, auditing provides assurance on the veracity of the financial health of companies. In particular, it points out that robust audit is key to re-establishing market confidence. These considerations point to the great significance of audit in the current economic environment and in the capital markets (Humphrey et al. 2009; Fogarty and Rigsby 2010). It is therefore in the public interest to suitably regulate access to the auditing profession.

Access to the profession can only take place after a controlled stage of theoretical training and guided practical training. These stages conclude with the sitting of an examination. To date, in line with international pronouncements on entry requirements for the auditing profession, Spain requires theoretical training, practical training and the passing of an entry test.

Article 7 of Law 12/2010 on Auditing deals with the authorisation and registration with the ROAC (the Official Spanish Registry of Auditors) and does not propose major changes in the essential regulations for access to the auditing profession. To date, universities and professional corporations have been relied upon to deliver the required theoretical training. Practical preparation must ensure that auditors have in-depth knowledge of their mission and are able to organise their work to obtain the necessary evidence to form a professional opinion that will enable them to draft and defend their audit reports. The aptitude examination 
includes (a) an initial theoretical part which may be dispensed provided the necessary knowledge has been acquired at officially recognised centres and (b) a second practical part that all candidates must take.

The presentation and analysis of current requirements in Spain highlight some weak points, both because of the time that has elapsed since the requirements were established and in view of international statements. Below is a presentation of what we believe the next reform of the system should include.

As regards the theoretical training of auditors in the new context of new European High Education Area, greater detail is required in the courses for the theoretical training of candidates as official university qualifications now have a much more flexible scheme. We consider that the definition of the curricular content must be offered in ECTS credits as it would guarantee immediate comparability in the European Union. The emphasis should be not only on the theoretical knowledge demanded of trainee auditors but also on the skills necessary to perform the audit (IES 3) and issues of ethics and independence (IES 4, IEPS 1). As a result, a need to produce complete teaching guides arises so as to ensure a pedagogical approach to the courses and better monitoring of course development and subsequent evaluation of the knowledge acquired.

Trainee auditors should be given integral practical training. Adequate practical training could be ensured by regulating the contractual link between the candidate and the employer as well as defining the mentor's work.

In this regard, it would be advisable to ensure certain levels of commitment from mentors with the candidates while also designing a due-process for monitoring the practical experience. A record should be kept of all the tasks candidates learn and perform with a view to complying with a well-defined experience syllabus. One of the most interesting issues for developing the practical experience period is the availability of good mentors. These mentors must offer the student appropriate training and supervision.

And finally, there is a need to reconsider whether access examinations should verify not only knowledge but also skills. Good professional skills will surely enhance candidates' ability to cope in the present business environment, which is why it is so important that at the training stage trainees must learn these professional skills under the supervision of a mentor.

\section{Conclusions}

One of the ideas suggested by the analysis in this article on the entry requirements to the auditing profession is that there are many similarities in the countries we have analysed yet there are also interesting discrepancies. International accounting literature on the differences between the Anglo-Saxon and the Continental accounting systems can help us explain many of the differences between countries, however, even though currently the European Union has aligned its own accounting model with IASB standards and is promoting higher harmonisation also in auditing through the use of the International Standards on Auditing (by the IFAC). 
Therefore, the main conclusion of this paper is to support progress towards harmonisation in the initial training and education of auditors to gradually converge the entry requirements to become a statutory auditor. To date, harmonisation in the auditing sector has been defined by Article 26 of the Directive that indicates that 'Member States shall require statutory auditors and audit firms to carry out statutory audits in compliance with international auditing norms adopted by the Commission. Member States may apply a national auditing standard as long as the Commission has not adopted an international auditing standard covering the same subjectmatter'. This article of the Directive is a clear commitment on the part of the European Union to IFAC auditing standards.

But, is there any point in having internationally harmonised technical auditing standards (ISA) if auditor training and education to entry in the profession has not been harmonised? Theoretical training, years of practical experience and an aptitude examination are dealt with by Member States regulations in the field. However, specific details are missing on skills assessment, control over practical training and content of entry examinations. Progress towards harmonisation in this field, in our opinion, will be achieved more easily if adoption of IES and IEPS issued by the International Auditing Education Standards Board (IAESB) of the IFAC is encouraged. The debate over the initial training and education of auditors is extremely important as it will facilitate the adaptation of audits to their intended aims to defend the public interest. Also and not less importantly, it will ensure uniform rules of access to the supply of audit services at a global level. This convergence will undoubtedly provide higher quality audits and a better definition of the rules of play in a global market.

\section{Appendix}

See Table 3

Table 3 Comparative table of entry requirements (adapted from the information provided to IFAC in the framework of its Compliance Program for IFAC members and associates)

\begin{tabular}{|c|c|c|c|c|c|}
\hline Countries & $\begin{array}{l}\text { Skills } \\
\text { consideration }\end{array}$ & $\begin{array}{l}\text { Theoretical } \\
\text { training }\end{array}$ & $\begin{array}{l}\text { Practical } \\
\text { training }\end{array}$ & $\begin{array}{l}\text { Is there a practical } \\
\text { experience mentor? }\end{array}$ & Examination \\
\hline Germany & $\begin{array}{l}\text { In line with } \\
\text { IES }\end{array}$ & Universities & $\begin{array}{c}3 \text { years register } \\
\text { of activities }\end{array}$ & There is a mentor & $\begin{array}{l}\text { Six-monthly } \\
\text { examination } \\
\text { with an oral } \\
\text { component }\end{array}$ \\
\hline Canada & $\begin{array}{l}\text { Wants to } \\
\text { introduce } \\
\text { IES and } \\
\text { IEPS }\end{array}$ & $\begin{array}{l}\text { Universities } \\
\text { and } \\
\text { Corporations }\end{array}$ & $\begin{array}{l}\text { Minimum } \\
3 \text { years, } 2 \text { at } \\
\text { senior level }\end{array}$ & $\begin{array}{l}\text { Wants to introduce } \\
\text { mentors }\end{array}$ & $\begin{array}{l}\text { Six-monthly } \\
\text { examination. } \\
\text { Follows IES } \\
6\end{array}$ \\
\hline China & $\begin{array}{l}\text { Going to } \\
\text { introduce } \\
\text { IES }\end{array}$ & $\begin{array}{l}\text { No specific } \\
\text { training }\end{array}$ & $\begin{array}{l}2 \text { years with a } \\
\text { Chinese audit } \\
\text { firm }\end{array}$ & $\begin{array}{l}\text { Authorised tutor. } \\
\text { No control or } \\
\text { monitoring. }\end{array}$ & $\begin{array}{l}\text { Yearly } \\
\text { examination }\end{array}$ \\
\hline
\end{tabular}


Table 3 continued

\begin{tabular}{|c|c|c|c|c|c|}
\hline Countries & $\begin{array}{l}\text { Skills } \\
\text { consideration }\end{array}$ & $\begin{array}{l}\text { Theoretical } \\
\text { training }\end{array}$ & $\begin{array}{l}\text { Practical } \\
\text { training }\end{array}$ & $\begin{array}{l}\text { Is there a practical } \\
\text { experience mentor? }\end{array}$ & Examination \\
\hline Spain & $\begin{array}{l}\text { Doesn't } \\
\text { follow IES }\end{array}$ & $\begin{array}{l}\text { Universities } \\
\text { and/or } \\
\text { corporations }\end{array}$ & $\begin{array}{l}3 \text { years, two } \\
\text { with auditor }\end{array}$ & Doesn't exist & $\begin{array}{l}\text { Written } \\
\text { examination, } \\
\text { no } \\
\text { established } \\
\text { periodicity }\end{array}$ \\
\hline USA & Follows IES & Universities. & $\begin{array}{l}1 \text { or } 2 \text { years of } \\
\text { practice The } \\
\text { candidate } \\
\text { produces a } \\
\text { report }\end{array}$ & Doesn't exist & $\begin{array}{l}\text { Written } \\
\text { examination }\end{array}$ \\
\hline France & $\begin{array}{l}\text { Going to } \\
\text { introduce } \\
\text { IES }\end{array}$ & $\begin{array}{l}\text { Universities } \\
\text { together with } \\
\text { the Ministry } \\
\text { of Education } \\
\text { and CSOEC } \\
\text { and CNCC }\end{array}$ & $\begin{array}{l}3 \text { years ( } 2 \text { at } \\
\text { least with an } \\
\text { auditor) } \\
\text { Candidates } \\
\text { acquire } \\
\text { diversified } \\
\text { experience }\end{array}$ & Authorised mentors & $\begin{array}{l}\text { Yearly } \\
\text { examination } \\
\text { with a written } \\
\text { and oral part }\end{array}$ \\
\hline Ireland & $\begin{array}{l}\text { Syllabuses } \\
\text { are } \\
\text { reviewed } \\
\text { according } \\
\text { to IES }\end{array}$ & $\begin{array}{l}\text { Universities } \\
\text { and/or } \\
\text { corporations }\end{array}$ & $\begin{array}{l}3 \text { years in } \\
\text { specific areas }\end{array}$ & $\begin{array}{l}\text { A mentor evaluates } \\
\text { the activities and } \\
\text { presents it to the } \\
\text { corporation }\end{array}$ & $\begin{array}{c}\text { Annual written } \\
\text { examination }\end{array}$ \\
\hline Italy & $\begin{array}{l}\text { IES taken } \\
\text { into } \\
\text { account }\end{array}$ & $\begin{array}{l}\text { Universities } \\
\text { together with } \\
\text { corporations }\end{array}$ & 3 years & $\mathrm{n} / \mathrm{a}$ & $\begin{array}{l}\text { Written and } \\
\text { oral } \\
\text { component }\end{array}$ \\
\hline Japan & Follows IES & $\begin{array}{l}\text { Course by the } \\
\text { corporation } \\
\text { for those who } \\
\text { pass the CPA } \\
\text { examination }\end{array}$ & $\begin{array}{l}\text { Minimum } \\
2 \text { years in an } \\
\text { audit firm }\end{array}$ & $\mathrm{n} / \mathrm{a}$ & Annual \\
\hline $\begin{array}{l}\text { United } \\
\text { Kingdom }\end{array}$ & Follows IES & $\begin{array}{l}\text { Universities } \\
\text { and other } \\
\text { private } \\
\text { teaching } \\
\text { bodies }\end{array}$ & $\mathrm{n} / \mathrm{a}$ & $\begin{array}{l}\text { The mentor } \\
\text { registers the } \\
\text { activities and } \\
\text { evaluates them in } \\
\text { a report which is } \\
\text { sent to the } \\
\text { corporation. }\end{array}$ & $\begin{array}{l}\text { Six-monthly } \\
\text { written } \\
\text { examination } \\
\text { on case } \\
\text { studies. }\end{array}$ \\
\hline
\end{tabular}

\section{References}

Allen, A., \& Woodland, A. (2010). Education requirements, audit fees, and audit quality. Auditing: A Journal of Practice and Theory, 29(2), 1-25.

Armitage, J. (2008). Changes in the importance of topics in auditing education: 2000-2005. Managerial Auditing Journal, 23(9), 935-959.

Crawford, L., Helliar, C., \& Monk, E. A. (2011). Generic skills in audit education. Accounting Education: An International Journal, 20(2), 115-131.

Defond, M., \& Francis, J. (2005). Auditing research after Sarbanes-Oxley. Auditing: A Journal of Practice and Theory, 24(supplement), 5-30. 
European Commission. (2006). Directive, 2006/43/EC of the European Parliament and of the Council of 17 May 2006 on statutory audits of annual accounts and consolidated accounts, amending Council Directives 78/660/EEC and 83/349/EEEC and repealing Council Directive 84/253/EEC.

European Commission. (2010). Green Paper. Audit policy: Lessons from the crisis.

Fogarty, T. J., \& Rigsby, J. T. (2010). A reflective analysis of the 'new audit' and the public interest: The revolutionary innovation that never came. Journal of Accounting and Organizational Change, 6(3), 300-329.

Garcia-Benau, M. A., \& Zorio, A. (2004). Audit reports on financial statements prepared according to IASB standards: Empirical evidence from the European Union. International Journal of Auditing, $8(3), 237-252$.

Humphrey, C., Kausar, A., Loft, A., \& Woodos, M. (2011). Regulating audit beyond the crisis: A critical discussion of the EU Green Paper. European Accounting Review, 20(3), 431-457.

Humphrey, C., Loft, A., \& Woods, M. (2009). The global audit profession and the international financial architecture: Understanding regulatory relationships at a time of financial crisis. Accounting, Organizations and Society, 34(6/7), 810-825.

IFAC. (2010a). Handbook of international education pronouncements (2010 edition). ISBN 978-160815-067-0.

IFAC. (2010b, April). IAESB 2010-2012. Strategy and Work Plan. New York.

Khalifa, R., Sharma, N., Humphrey, C., \& Robson, K. (2007). Discourse and audit change: Transformations in methodology in the professional audit field. Accounting, Auditing and Accountability Journal, 20(6), 825-854.

Mcpeak, D., Pincus, K. V., \& Sundem, G. L. (2012). The International Accounting Education Standards Board: Influencing global accounting education. Issues in Accounting Education, 27(3), 743-750.

O'leary, C. (2012). Semester-specific ethical instruction for auditing students. Managerial Auditing Journal, 27(6), 598-619.

Quick, R., Turley, S., \& Willekens, M. (2008). Auditing, trust and governance. Developing regulation in Europe. London: Routledge.

The Common Content Project. (2010a, October). Compliance Manual.

The Common Content Project. (2010b, October). Learning Outcomes and Knowledge.

The Common Content Project. (2010c, October). Organizational Document.

The Common Content Project. (2010d, October). Qualifications Requirements.

The Common Content Project. (2010e, October). Skills Framework.

UNCTAD-ISAR. (2003). Modelo revisado de plan de estudios de contabilidad. Informe de la secretaría de la UNCTAD. Ginebra. (TD/B/COM.2/ISAR/21).

Zorio, A., García-Benau M.A., \& Novejarque J. (2010, Junio). Las Normas Internacionales de Auditoría: Nuevo reto para la profesión. Revista AECA. No. 90, 2010, 15-19. 